\title{
From the Reality of Work to Grounded Work-Based Learning in German Vocational Education and Training: Background, Concept and Tools
}

\author{
Michael Gessler* \\ University of Bremen \\ Institute Technology and Education (ITB) \\ Am Fallturm 1, 28359 Bremen, Germany \\ E-mail:mgessler@uni-bremen.de
}

Falk Howe

University of Bremen

Institute Technology and Education (ITB)

Am Fallturm 1, 28359 Bremen, Germany

E-mail: howe@uni-bremen.de

* Corresponding author

Received: 01 November 2015; Accepted: 10 December 2015; Published online: 15 December 2015

\begin{abstract}
The "Riga Conclusions" of the European Ministries of Education of 22 June 2015 for the orientation of vocational education and training in Europe are promoting work-based learning as one of five "medium-term deliverables" for the next five years. But: How should and can work-based teaching and learning be designed? Our approach was developed within the German Dual VET System. Therefore it is not surprising that the work reality is for us the major principle for designing curricula and learning settings. As a starting point for developing didactical measures in the field of vocational education and training it is crucial in this approach to identify practices, routines and experiences of skilled workers that are experts for what they are doing. What are those people doing when handling a task, how are they acting, what work objects and tools are they operating with, and what requirements do they have to be aware of? To answer these kinds of questions, the real work in practice must be explored. A useful approach for doing this is a vocational work process analysis. The next step comprises developing a workbased learning project for the classroom. These two steps, vocational work process analysis and work-based learning projects, build the core of the article and enable a grounded work-based learning. Additional the changing priorities of curriculum design in the last century are introduced to reach a better understanding of the background and the actual work-oriented focus in German Dual VET. Our key proposition is: If work-based learning in vocational schools is wanted, the gap between the reality of work and the formal learning settings has to be closed.
\end{abstract}

Keywords: Vocational Education and Training, Work-based Learning, Reality of Work, Curriculum Development, Competence Development 


\section{Bibliographical notes:}

Dr Michael Gessler is a Professor at the Institute Technology and Education at the University Bremen, Germany. His research interests focus on transfer and innovation research in vocational education and training, vocational didactics, work-based learning, professional development and school-to-work transition.

Dr Falk Howe is a Professor at the Institute Technology and Education at the University Bremen, Germany. His research interests cover technology enhanced learning, technical and vocational didactics, work-based learning, competence development and occupation-related qualification research with emphasis on technical domains. 


\section{Introduction}

In the German Dual System, vocational education and training takes place in parallel in two places of learning: three days of vocational training at a company and two days of vocational education at the vocational school. Attending a vocational school is arranged via legal compulsory education. The apprentices in turn conclude a training contract with the company for the duration of the training. Apprentices are therefore not just interns, but members of the company for the duration of their training (usually 3 years). Transition from school to work is carried out not only once at the end of their training, but weekly. It is therefore not surprising that the transition from VET to a subsequent professional activity usually runs smoothly. It is also unsurprising that teaching and learning at a vocational school is geared towards the reality of work and not towards the structure of academic disciplines or academically structured knowledge. This was not always the case (Gessler and Howe 2013).

A key question when developing curricula is to decide how to orient the objectives, content and methods and how to justify their relevance. This justification is important, as every curriculum represents normative stipulations. Reetz (1984), in reference to Robinsohn (1967), identified three contexts of justification: the principles of personality, science and situation.

- The principle of personality ties to the personality to be developed and it orients the choice of content towards an educational objective or educational ideal. How is a person, how could and ought he or she be, and: how should he or she be? The key question here is by what norm this "should" should orient itself. According to the ideals of an ethical-religious individual, a competent person and/or an emancipated member of civil society?

- The scientific principle is oriented to the structure of the sciences (i.e. engineering). The idea here being that the academics research and systematise an object or specific area, pass the content structured by subject to the teachers and the teachers in turn pass the material onto the students in pedagogically adjusted form.

- The situation principle is oriented towards current or future situations in the family, at work or in the society. Initially, current or future situations that require mastering have to be identified. Following on, the required competences need to be ascertained and then, using these competences as guidelines, material content and learning tasks can be derived. The acquisition then takes place in reverse order: use the content and tasks to attain competences that can be used to handle situations.

In order to understand the present alignment in the German Dual System, work situation as priority 1 , it is helpful to make certain the historical development and context.

In the first step, we will demonstrate with a brief historical overview how vocational training in Germany initially began with a focus on skilled work, lost this focus at vocational schools in the course of the academic professionalisation of teachers, and, after massive criticism from the business community, returned to focusing on skilled work. In the second step, we will show how to design grounded work-based teaching and learning in vocational schools on the basis of this prevailing principle that is defined by the focus on work, occupations, and skills. 
Finally, we will discuss the level of implementation in Germany as well as challenges for further refinement.

\section{Background}

At the beginning of the 20th century in Germany, the purely company-based vocational training was complemented by a second pillar: school-based vocational education. This was not due to the desire to improve the quality of vocational training, nor it was initiated or welcomed by the companies, but the desire to solve an increasingly intensifying societal problem: because compulsory education ended at the 15th birthday and military service only started at 21 , there was a vacuum in secondary educational. This vacuum combined with a problematic social situation (industrialisation) led to the situation in which many adolescents became vagabonds without any direction. They represented a two-fold risk to the order of the imperial state in the 20th century: on the one hand, they were susceptible to the revolutionary socialistic thinking of the working-class movement and, on the other hand, they were of no "use" to the imperial military (Greinert and Wolf 2013).

These problems were solved, from the perspective of the ruling class, when the idea was expressed to complement compulsory general education through secondary compulsory school-based vocational education (three more years), ensuring that adolescents learn to (1) dutifully perform an occupation, (2) in order to take up a societal function using their skills, (3) thus stabilising their imperial state as dutiful citizens (Kerschensteiner 1901). According to Georg Kerschensteiner (founder of the vocational schools in Germany), such schoolbased vocational education would have to be grounded on work, not purely theory: "Crafts are not just the basis of all art, but also the basis of any real science. A public school designed to prepare for intellectual and manual professions is badly organised if it does not offer any facilities to develop the practical inclinations and abilities of a pupil." (Kerschensteiner 1922, p. 28, translated from German by the authors). With this demand, Georg Kerschensteiner refers both to Heinrich Pestalozzi (1746-1827) and John Dewey (1859-1952). He felt the greatest shortcoming that general education schools had to be accountable for what they did not consider: Dewey's "fundamental theorem of intellectual education", wherein intellectual development "always progressed from practical interests to the theoretic" (ibid., p. 41, translated from German by the authors).

Here the principles of "work situation" and "personality" become clear: Learning how to perform an occupation dutifully (principle of situation) is linked to developing civic virtues (principle of personality). Education should therefore be geared towards practical interests and skills. Its model example is the autonomous master craftsman. With this educational concept, Kerschensteiner creates a fundamental idea, which had a sustained impact on vocational education and training in Germany and, despite the later-mentioned departure and orientation towards the scientific principle, has always remained as the fundamental idea of vocational education and training in Germany.

With the progress of industrialisation and the industry's increasing influence, a new orientation evolved: from the 1920s instead of the autonomous master craftsman, it is the subservient industrial worker who provides the model example, which means the personality-orientation loses relevance. This reorientation also makes the holistic relationship of the occupation (situation principle) obsolete. The ideas of "scientific management" by Frederick Winslow Taylor supported the process of fragmentation and brought about an orientation towards scientific 
knowledge (e.g. engineering). The division between the learning places in companies and schools takes shape and the systems dissociate themselves. The vocational school is henceforth responsible for theoretic knowledge education, while the company takes over the practical training. The school-based vocational education is given a new framework and within these boundaries a process of professionalisation sets in: as part of a first step, the content of the curricula is reclassified as fundamental theoretical knowledge and advanced applied knowledge. While the basic knowledge no longer demonstrates any relevance to operational professional activities, the advanced knowledge is still initially oriented to operational activities that are, however, already subjected to a Taylorisation (Gerds 2001).

In the beginning of the 1960s, the professionalisation of school-based vocational education in the technical area finally also reaches the teachers. The provision of teacher education then switched from the pedagogical institutes to universities, which also meant the entrance requirements changed. Instead of vocational experience, the general educational Abitur (equivalent to A-levels in UK, High School Degree in the United States and the BAC in France) and a short industrial internship were now preconditions for to enter teacher training. Subsequently, technology-oriented students of teacher education particularly attend engineering courses and commerce-oriented students of teacher education particularly attend economy-related courses in the universities. Key model examples are the academically-qualified "Diplom-Ingenieur" (graduate engineer) or the similarly academically-qualified "Diplom-Kaufmann" (business studies graduate). The universities' concept of being academically-oriented rather than practice-oriented, has been socialising this generation of teachers at vocational schools until today (Lipsmeier 1998).

On 13th February 1970, the "Deutscher Bildungsrat" (a commission founded in 1965 by the Federal Government and the state governments that operated from 1966 to 1975) published general recommendations for teacher education. These were: (1) the principle of science-orientation: "the scientific orientation of subject matter and learning method is valid for all age groups" (Deutscher Bildungsrat 1972, p. 33, translated from German by the authors) and (2) the principle of rationality: "Besides the learning objectives and contents, the curriculum also determines the respective orders and learning steps as well as the various methods, materials and educational technologies. The learning objectives must be monitored." (ibid., p. 63, translated from German by the authors). The recommendations strengthen the already existing scientific principle, which is why in their vocational schools the academically-trained teachers find a curriculum consisting of subject areas, narrowly formulated learning objectives and extensive abstract content catalogues.

During the 1980s, school-based education within the dual system of vocational education and training saw heavy criticisms. The industry's representatives particularly criticised that the school-based education was too far from reality, not contributing towards tackling the challenges of working life in the industry. In other words: the schools were not oriented towards the customer (Hüster and Gravert 2001). Initially, Germany's Federal Institute for Vocational Training (BIBB Bundesinstitut für Berufsbildung) and its industrial social partners reacted to the growing critique with the upcoming reorganisation of metal and electrical occupations between 1987 and 1989. One key component of the reorganisation was that self-governance as the ability for autonomous planning, 
autonomous implementation and autonomous monitoring was back in focus (the personality principle). As a consequence, the in-company practical examination was also modified: while previously only a job's final outcome was assessed, now an examinee's skills demonstrated in-situ are assessed additionally to the outcome. The commission working in parallel to develop the teaching curricula for metal and electrical engineering in vocational schools also orient themselves according to the principle of personality. Their shared orientation was the model example of "autonomous action". Shortly afterwards, in 1991, the Conference of the Ministers of Education and Cultural Affairs (in German: Kultusministerkonferenz = KMK) passed a framework agreement for vocational schools, setting decisive parameters. The vocational school's objective would be to provide a vocational education and extend the previously acquired general education. The vocational school aims to provide the apprentice with the abilities to fulfil their occupation socially and ecologically responsibly and participate in shaping their working environment and community (KMK 1991).

In 1992, the KMK reacted once more to critique against vocational education and appointed a commission to revise the recommendations for the preparation of KMK framework curricula for the school-based education. The commission submitted its first output in 1996. This was first tested in individual occupations and then passed as a binding basis. What exactly are the recommendations that were compiled by the commission? The "recommendations" describe how KMK framework curricula for vocational schools are developed, how they should be designed and what they should contain. Particularly the school-based vocational education is formulated and the guideline is laid down that KMK framework curricula are to be structured using "areas of learning". Because the KMK framework curricula are mostly adopted directly in the 16 federal German states (e.g. Bavaria, North Rhine-Westphalia) as curricula, these recommendations directly influence the education at the vocational school (Gessler 2016).

The new curricula concept of "areas of learning" does not completely abolish the dominant scientific principle, but it did reintroduce the situational principle, and the concept included above all that the scientific principle starts to fulfil a kind of service provider function for the situational principle: "Areas of Learning are ... thematic units that are oriented towards vocational tasks and procedures. In special cases, thematic units can also be included within areas of learning from an academic point of view. In any case, even for such units the connection with the vocational work process should be made clear. Conveying orientational knowledge, system-oriented thinking and action, solving complex and example tasks as well as networked thinking are promoted particularly within an action-oriented classroom. It is therefore indispensable that the respective work and business processes are provided with the relevant academic background information." (KMK 1996/1999, p. 14, translated from German by the authors). Three different stages of orientation in vocational education can be identified (Tab. 1):

Tab. 1: Changing Priorities in Curriculum Design

\begin{tabular}{|c|c|c|c|}
\hline & 1900 & 1970 & since 2000 \\
\hline $\begin{array}{l}\text { Priority } 1 \\
\text { Priority } 2 \\
\text { Priority } 3\end{array}$ & $\begin{array}{l}\text { Work } \\
\text { Personality }\end{array}$ & Science & $\begin{array}{l}\text { Work } \\
\text { Personality } \\
\text { Science }\end{array}$ \\
\hline
\end{tabular}


Hereinafter we are focussing on the first two priorities: work situation and personality. Nevertheless all principles are important and especially their combination (Gessler 2016).

\section{Conceptual References}

In the first step, the conceptual references of the approach are outlined. Following this, the concept itself is presented. Four conceptual basics are the foundation of our grounded work-based learning approach: (1) Learning-theoretical foundations, (2) occupational competence as a basic objective, (3) work process orientation as a design framework and (4) project-based learning and working as a learning approach.

\section{Learning-theoretical foundations}

Learning-theoretical foundations provide findings on situated cognition and situated learning (Collins et al. 1989; Rogoff 1990; Cognition and Technology Group 1990; Lave and Wenger 1991; Greeno et al. 1993; Gessler 2009). Despite different emphases, these theories are based on the common assumption that learning is an active, individual construction process in conjunction with the preexisting knowledge and experience of the learner, that acquiring skills cannot be separated from their practical application in a community of practice, and skills are to be regarded as highly context-bound. In order to ensure the transfer of what has been learned, the learning situation of the subsequent application situation should be as similar as possible, i.e. situational. A learning situation should therefore be an interesting, authentic problem or task that is integrated in a real job-related situation. Multiple perspectives and contexts are open to the students in the learning process for the holistic development, abstraction, and flexible transferability of knowledge to other, similar tasks, and they are given the opportunity to continuously articulate and reflect on their actions. Learning in groups should be initiated in a targeted and meaningful way in this regard (Gerstenmaier and Mandl 1995; Mandl et al. 2002).

\section{Occupational competence as a basic objective}

In the discussion about practical orientation in vocational training, there was criticism early on that competent professional action is more than just an organised consequence of purpose-rational action steps (Rauner 1995, p. 5). Professional skill is shown more in the combination of expertise with general social and personal competences as well as the ability to influence the world of work and the business. This broader understanding of vocational training was already reflected in the educational mission of the KMK formulated at the beginning of the 1990s (KMK 1991); a comparable objective has now been formulated for in-company vocational training that is now admitted in the German Qualifications Framework (Arbeitskreis Deutscher Qualifikationsrahmen 2011), for example. Based on "Pedagogical Anthropology" (Roth 1971) and the concept of shaping (Rauner 1988), the term for comprehensive occupational competence as the ability and willingness to work self-responsibly, appropriately, and in a personally thoughtthrough way in social responsibility was established (KMK 2011, p. 15; Arbeitskreis Deutscher Qualifikationsrahmen 2011, p. 4; Bundesinstitut für Berufsbildung 2006, p. 21). Occupational competence includes the aspects of professional, social, and personal skills and focuses on individual and holistic personality development as the core of vocational training processes (Gessler 
2010). At the same time, we take into account the fact that technology can be shaped, requires design, and has a purpose (Rauner 1995).

\section{Work process orientation as a design framework}

At the end of the 20th century, the combination of learning and working went through a renaissance in training and continuing education and was also used in the area of vocational training in various forms (Lipsmeier 1996, p. 205; Frieling 1995). The qualification and educational potential of the working reality with their professional work tasks was (re)discovered as a central reference point for vocational education and training (cf. for example the series of pilot projects "Learning in the work process" from 1990 to 1996: Dehnbostel et al. 1992, or the results of the project "Qualification Development Management", QUEM 2000). Concepts such as learning on the job, workplace learning, learning at work, joboriented learning, learning on the sales order, or decentralised learning follow the common approach of integrating the workplace and the work processes to be accomplished in training measures so as to be able to better meet the changing skill requirements (Dehnbostel 2002, 2007). This turn to the process of labour is also reflected in the above-mentioned KMK agreement to structure curricula according to areas of learning. Subject classifications (scientific principle) should not be constitutive for vocational curricula, rather job-related tasks and problems that are derived from professional fields of activity. This orientation led to a common reference point in dual vocational training, which meant the issue of cooperation in the system of duality could be designed differently. The idea of partnershiporganised training is on the one hand not new and can be seen throughout the entire history of the dual system. However, generally cooperative training was judged more as a stopgap and crisis measure, which was intended to help secure or create training places and ensure training was complete (Bundesinstitut für Berufsbildung 1995; BMBF 1997). On the other hand, since the mid-1990's the potential of cooperation between learning locations for high quality, attractive, and yet costeffective vocational training could increasingly be seen (Holz et al. 1998a; Pätzold and Walden 1999; Rauner 2003). Against this background, and in connection with the demand for comprehensive vocational competence, the question of contentrelated cooperation between partners was again raised. In overcoming an analytical separation of theory and practice, both the business as well as vocational education in schools, albeit with different perspectives and requirements, raise the work process and professional work tasks to their central reference point.

\section{Project-based learning and working as a learning approach}

In the 1980s, the concept of full working action and business activities became increasingly more important. Encouraged by the response to the changing qualification requirements debate about what were called "key qualifications" (Mertens 1974), company vocational training was designed to be action-oriented through methods such as project work (Laur-Ernst et al. 1996) and key text methods (Reetz 1990). Action-oriented is particularly aimed at the integrated teaching of theoretical knowledge and practical skills via reality and problembased learning, which includes social action and is controlled by the learners themselves (Wittwer 2000, p. 13; Pätzold 1992; Adolph 1996).

Project-based learning and working is particularly suitable for implementing work process orientation and to encourage developing the comprehensive ability to act - in the sense of the above-described triad of professional, social, and personal 
skills. Problem-solving processes are fundamental to the development of expertise, which are divided into four phases: (1) understanding the problem, (2) developing a plan (3), executing the plan, and (4) review (Pólya 1964; Gessler and UhligSchoenian 2013). Acquiring social competence in turn requires a medium: a cooperating group that is pursuing a common objective, operates as a team and interdependently, and while doing so must learn to deal with motivation gains and losses (Locke and Latham 2002; Johnson and Johnson 2003; Schulz-Hardt et al. 2007). The development of personnel competence is after all integrated in the exchange ratio of professional respect, sociality, and personalisation. It is based on self-learning processes that, depending on the accentuation, is referred to as selfdirected learning (Knowles 1975), self-regulated learning (Boekaerts 1999), selfpaced learning (Faulstich et al. 2002), and self-organised learning (Gessler 2010).

The importance of domain-specific prior knowledge for acquiring skills is undisputed today. It serves - particularly in learning and work settings with a high level of freedom - to help with control and guidance for perception and comprehension processes (Weinert 1994; Knöll et al. 2007).

\section{Vocational Work Process Analysis}

Occupations are the major organisation principle for work, teaching and learning in Vocational Education and Training in Germany. This orientation is sometimes questioned or even criticized from politicians, researchers or practitioners from other countries. Sceptical voices are e.g.: "This occupation orientation is just possible in a country with a strong economy, if it is founded on a long tradition, and if the companies are willing to pay for it." What is neglected in these voices is, that in all economies, stronger or weaker, the problem of work organisation has to be solved. Occupations are a solution. And, occupations exist in all countries. The difference is that we distinguish in Germany between gainful occupations (in German: Erwerbsberufe) and training occupations (in German: Ausbildungsberufe). Not all gainful occupations need an intensive three-year-training. And, occupation which requires training offer the option for variant gainful occupations. There are actual around 330 training occupations (Bundesinstitut für Berufsbildung 2015), but 27.000 gainful occupations are listed in the German statistic (Bundesagentur für Arbeit 2010, 2015). The third point: Companies are willing to pay, if an offer fit to their needs. Training occupations are based on real needs and the reality of work. Occupation is therefore not a remaining traditional construct from the middle ages. It is useful to solve the problem of skill development and work organisation of skilled work in general.

Concepts for combining learning, teaching and work take the approach of bringing together the work place and the vocational education and training, in order to better fulfil the altered qualification requirements (Burchert et al. 2014). Therefore, a particular challenge for teachers and trainers is the identification of typical work situations and processes which are creating in their combination an occupational profile. In the next step the following points will be addressed:

- An approach to analyse and describe occupations and relating competence profiles.

- An approach to use this competence profile to design a didactical setting.

Engaging with the question how occupations can be described appropriately has always been a part of vocational research in Germany. Above all, this involves 
creating descriptions which lead to stable training occupations. In this context, stability means that training occupations do not have to be continually adapted to technological, organisational, economic and social change, rather they grow with this change and participate in it.

As a starting point for developing didactical measures in the field of vocational education and training it is crucial to identify practices, routines and experiences of skilled workers that are experts for what they are doing. What are those people doing when handling a task or solving a problem, how are they acting, what work objects and tools are they operating with, and what requirements do they have to be aware of? To answer these kinds of questions, the real work in practice must be explored: There must be precise questioning and observation of how an expert in a trade goes about his work (Knutzen et al. 2010).

\subsection{Describing Occupations}

The crucial pedagogical idea lies in describing occupations using their characteristic task areas, as opposed to concrete activities, tools or technologies. So for example, a typical skilled work task for an electrical fitter is the installation and set-up of lighting systems. This task already existed at the start of the 20th century and still exists to this day. What have changed however, are the lights themselves, the materials used during the installation, the installation regulations and the wishes of the customer and so on. But these changes do not compromise the appropriateness of the corresponding occupation, as long as the qualification involves the tasks in question and not the impartation of knowledge about a certain, potentially out-of-date, technology. This means the descriptions of task areas that we call vocational spheres of activity within an occupation is relatively stable. Nevertheless, also occupations disappear in the process of modernisation (Palla 2014).

A vocational work process represents the complete activity needed to fulfil an operational assignment. Vocational work processes are initiated by customer orders or internal company orders. The assignment goes through the phases of order/problem clarification, planning, implementation and completion. The result of the work is a concrete product or a service which can be given a value with regard to its worth in relation to the customer. A vocational work process is viewed by the skilled worker (journeyman, master craftsman) not as an isolated operation but as part of a wider context of skilled work.

In the area of industrial and technical occupations, it has proved useful to develop the title of a vocational sphere of activity based on a combination of substantive verbs directed at the work action (e.g. fitting, installing, commissioning, maintaining) and work objects (e.g. machinery, equipment, systems, devices): so a vocational sphere of activity might be "planning, installation and commissioning of lighting systems" (see fig. 1). Following our experience in the last years, 10 to 16 vocational spheres of activity are required to describe an occupation.

The definition of a system of vocational spheres of activity is carried out during a workshop with experienced experts in the field. These experts are predominantly skilled workers with long-term experience, qualified journeymen and master craftsmen. As preparation for an expert workshop, a vocational education researcher develops a preliminary system of vocational spheres of activity. For this purpose, he evaluates relevant specialist literature in order to identify important work objects and work actions which are key to the occupation. These are then combined as titles of vocational spheres of activity - according to 
the syntax depicted. The expert workshop then checks this preliminary system of vocational spheres of activity, and modifies it if required. Accordingly, the key result of the workshop is a validated, final system of vocational spheres of activity depicting an occupation. Fig. 1 shows such a system for the occupation of the electrical fitter (Howe and Knutzen 2014, p. 19, translated from German by the authors).

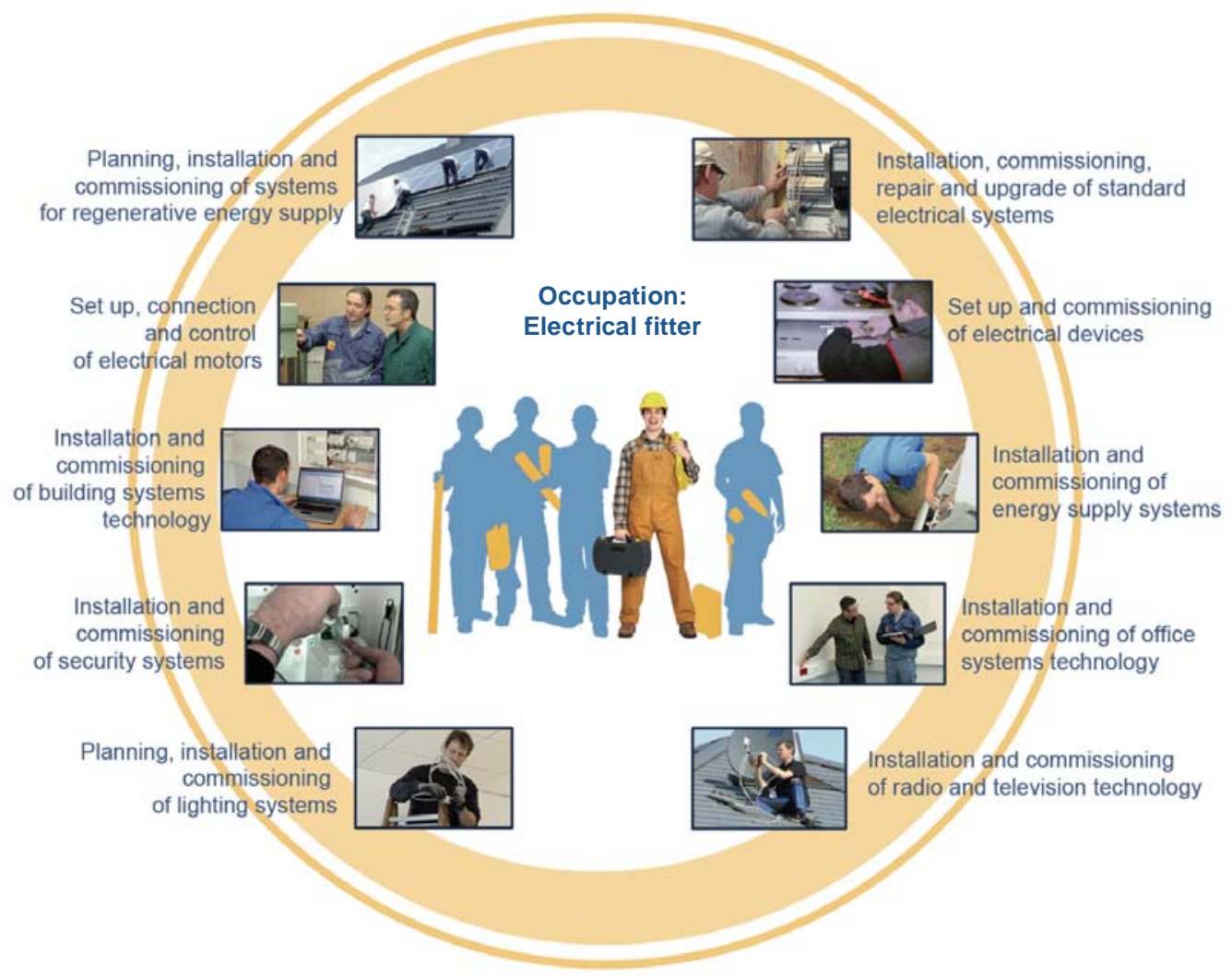

Fig. 1: Vocational spheres of activity of an electrical fitter

When carrying out a vocational work process analysis, the method of qualitative interview is employed. The interview is conducted with a vocational work process expert and helps record the various facets of the vocational work process. As a guiding principle for the interview, we provide the "Vocational Work Process Matrix". It sub-divides the vocational work process into four fundamental phases: Order/problem clarification, planning, implementation and completion. Furthermore these different phases are being expanded by several core questions which lead to detailed descriptions of the work steps and methods and work objects which are affiliated to the different phases. On top of that the vocational work process matrix consists of additional conditions like customer requirements, special company conditions, laws, regulations and mentionable standards.

\subsection{Analysing Vocational Work Processes}

A system of vocational spheres of activity is extremely helpful for understanding what is fundamentally for an occupation, and provides a good overview of the whole occupational area of responsibility. But the titles of the vocational spheres of 
activity are no longer adequate when looking at the details or the question what a skilled worker actually does when handling a task, how he acts, what work objects and tools he operates with, and what requirements he has to be aware of. To answer these kinds of questions, the real work in practice must be explored: There must be precise questioning and observation of how an expert in a trade goes about his work:

- Work steps and methods: What action steps do you go through in this phase of the vocational work process? How are these action steps executed?

- Work objects: What work objects (products, plant, machinery, devices, tools, materials, PC/software, documentation) are used to carry out the work in this phase of the vocational work process?

However, a vocational work process cannot be adequately described only using action steps, methods and work objects. Challenges, interests, influences and regulations also need to be included. The following conditions are added to the vocational work process matrix (Howe and Knutzen 2011a, p. 50):

- Customer requirements: What does the customer expect in this phase of the vocational work process with regard to service, quality and costs?

- Company conditions: Which staff is involved in this phase of the vocational work process? What resources are required in this phase of the vocational work process?

- Laws, norms, standards and regulations: What laws, norms, standards and regulations must be considered in this phase of the vocational work process?

These elements of a vocational work process lead to the following vocational work process matrix (Tab. 2):

\section{Tab. 2: Vocational Work Process Matrix}

\begin{tabular}{|l|l|l|l|l|}
\hline $\begin{array}{l}\text { Laws, norms, } \\
\text { standards and } \\
\text { regulations }\end{array}$ & & & & \\
\hline $\begin{array}{l}\text { Company } \\
\text { conditions and } \\
\text { rules }\end{array}$ & & & & \\
\hline $\begin{array}{l}\text { Customer } \\
\text { requirements }\end{array}$ & & & & \\
\hline $\begin{array}{l}\text { Vocational } \\
\text { work phases }\end{array}$ & $\begin{array}{l}\text { Order/Problem } \\
\text { clarification }\end{array}$ & Planning & Implementation & Completion \\
\hline $\begin{array}{l}\text { Work process, } \\
\text { work steps and } \\
\text { methods }\end{array}$ & & & & \\
\hline Work objects & & & & \\
\hline
\end{tabular}

The vocational work process matrix facilitates a very structured approach to the expert interview. It makes it possible to capture a detailed picture of a vocational work process, without losing an overall view. The interview partners agree on a concrete assignment for the analysis and first of all reconstruct the complete course 
of action. For this purpose, on the one hand, the expert depicts what individual work steps are followed when handling an assignment, and on the other, describes how the steps involved are completed methodically.

Once the process and methodological procedure for the whole vocational work process has been clarified, the individual vocational work phases are discussed. Phase by phase, the work objects used, the customer's expectations of service, quality and costs, personnel and material resources in the company plus the laws, regulations and standards to be observed are brought into the vocational work process matrix.

The vocational work process analysis is complete when all sections of the matrix have been discussed with the experts, and all entries made in the vocational work process matrix.

\subsection{Creating Vocational Spheres of Activity}

Vocational work process analyses create an empirical approach to skilled work. What has to be taken into account, however, is that vocational work processes are always specific: They depend on a very wide range of factors such as the size, type and organisational structure of the company, the type of customer and their wishes, the contract itself, the technology used, the infrastructure, the organisation of the work, the tools used, conditions on the building site etc. To avoid portrayal of individual cases, it is therefore important to aggregate the analysis of similar vocational work processes. Vocational spheres of activity cluster comparable vocational work processes together, generalise the results of the vocational work process analysis and exhibit their characteristics. Completed studies tells us that three to five vocational work process analyses are adequate to develop the description of a vocational sphere of activity. The three most important elements in the description of a vocational sphere of activity are the portrayal of the (1) typical orders/ problems to solve (milestones, vocational work process steps and explanatory note), (2) work flow (grouped in four phases: order/problem clarification, planning, implementation, completion), an (3) indication of the relevant vocational competence for each stage (clustered in three dimensions: professional, social, personal) and a listing of the work specifications (work objects, regulations, tools).

As vocational work processes have comparable structures in principle, the description of the typical work flow within the vocational sphere of activity is also sub-divided into the four vocational work phases (order/problem clarification, planning, implementation and completion). Within each phase it is then shown how the handling of an assignment which corresponds to this vocational sphere typically runs. Individual work steps may then be commented on, thereby clarifying the particular features of the vocational sphere of activity (see table 4, based on Howe and Knutzen 2011b, p. 45).

The second element of the vocational sphere of activity is the portrayal of the professional competence (table 5) which is required to manage the operational assignments and customer orders within that vocational sphere. This depiction is derived from a combination of professional, social and personal competence, and the vocational work phases in the form of a competence profile. The competence profile breaks down the required knowledge at each phase of the vocational work process, i.e. competence in these three areas lie behind the successful completion of each step. 
Tab. 4: Excerpt from a vocational sphere of activity: Phases milestones and vocational work process steps

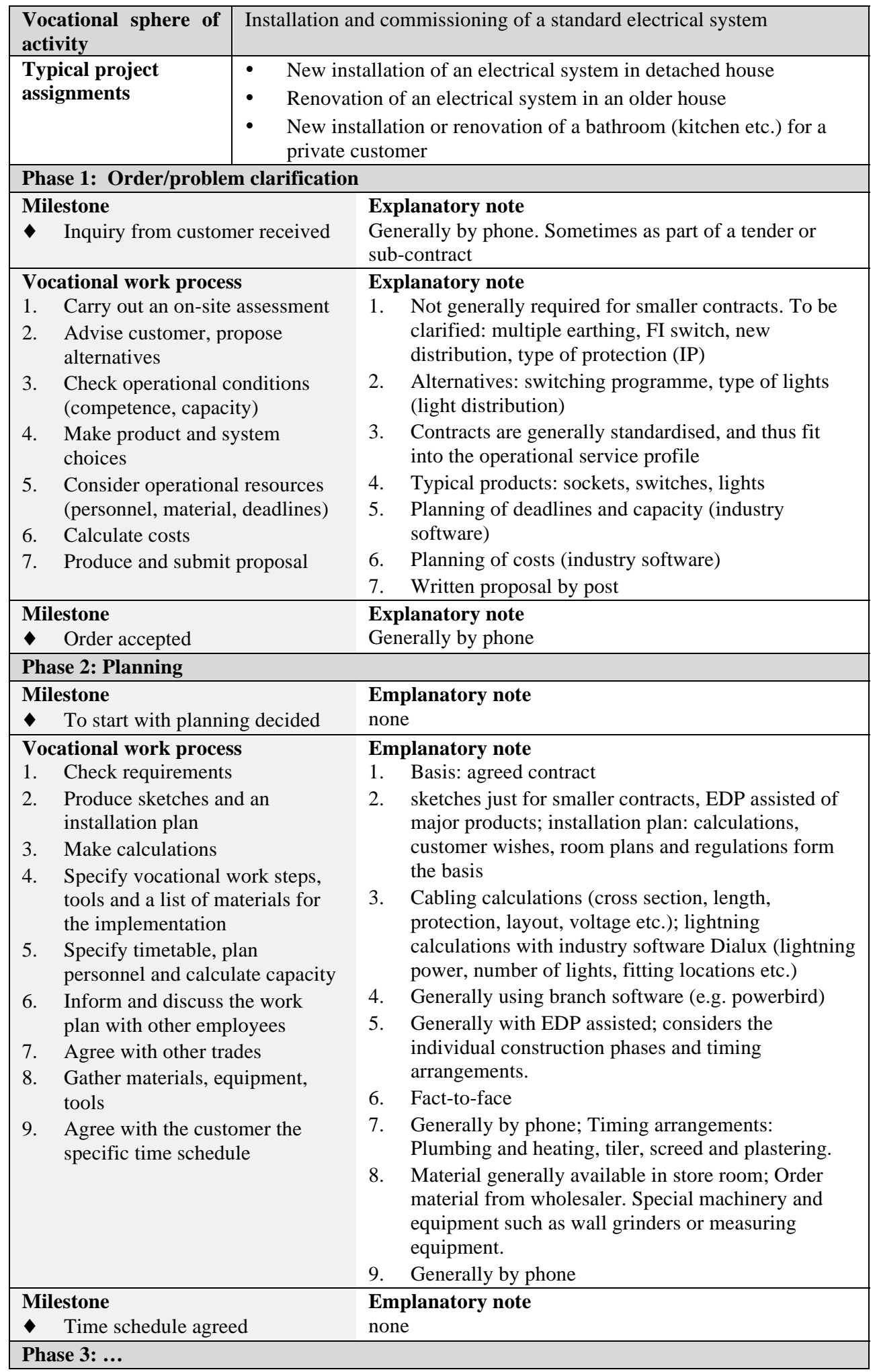


Tab. 5: Excerpt from a vocational sphere of activity: Competence profile

\begin{tabular}{|c|c|c|c|c|}
\hline \multicolumn{5}{|c|}{ Professional competence } \\
\hline & $\begin{array}{l}\text { Order/Problem } \\
\text { clarification }\end{array}$ & Planning & Implementation & Completion \\
\hline Professional & $\begin{array}{l}\text { Be able to compare } \\
\text { different technical } \\
\text { solutions related to } \\
\text { the customers } \\
\text { wishes } \\
\ldots\end{array}$ & $\begin{array}{l}\text { Be able to } \\
\text { produce } \\
\text { technical } \\
\text { drawings / } \\
\text { sketches } \\
\ldots\end{array}$ & $\begin{array}{l}\text { Be able to analyse } \\
\text { technical faults } \\
\ldots\end{array}$ & $\begin{array}{l}\text { Be able to } \\
\text { raise an } \\
\text { invoice } \\
\ldots\end{array}$ \\
\hline Social & $\begin{array}{l}\text { Be able to } \\
\text { communicate with } \\
\text { customer } \\
\text { appropriate } \\
\ldots\end{array}$ & $\begin{array}{l}\text { Be able to } \\
\text { communicate } \\
\text { with other trades } \\
\text { appropriate } \\
\ldots\end{array}$ & $\begin{array}{l}\text { Be able to } \\
\text { cooperate with } \\
\text { other trades and } \\
\text { employees } \\
\ldots\end{array}$ & $\begin{array}{l}\text { Be able to } \\
\text { provide the } \\
\text { customer with } \\
\text { further service } \\
\text { proposals } \\
\text {... }\end{array}$ \\
\hline Personal & $\begin{array}{l}\text { Be able to catch up } \\
\text { self-reliant with the } \\
\text { latest technology } \\
\text { (self-directed } \\
\text { learning) } \\
\ldots\end{array}$ & $\begin{array}{l}\text { Be able to reflect } \\
\text { the own working } \\
\text { methods (self- } \\
\text { reflexion) } \\
\ldots\end{array}$ & $\begin{array}{l}\text { Be able to insist on } \\
\text { observance of } \\
\text { health and safety at } \\
\text { work (self- } \\
\text { confidence) } \\
\ldots\end{array}$ & $\begin{array}{l}\text { Be able to } \\
\text { assess the } \\
\text { completed } \\
\text { project (self- } \\
\text { assessment) } \\
\ldots\end{array}$ \\
\hline
\end{tabular}

The function of the third part of the vocational sphere of activity is to provide a description of the content. This happens when the characteristic work objects (products, plant, machinery, devices, tools, materials, PC/software, documentation) plus the relevant legislation and regulations are listed. This list coincides with the elements from the vocational work process matrix. This means it is possible to combine it directly with the findings of the vocational work process analyses (table $6)$.

Fundamentally, when describing a vocational sphere of activity, the following should be noted: The amalgamation of the various vocational work process analyses is carried out under the premise of extracting the particular features in this vocational sphere. So it is not merely a matter of transferring all the results from the vocational work process analyses, rather only those which are characteristic of the vocational sphere of activity and may differentiate it from other vocational spheres.

The Vocational Spheres of Activity are on the one hand with the present curriculum approach of "Areas of Learning" in Germany (Gessler 2016). Both are focussing the same idea: An occupation is an integration of typical work tasks which can be grouped together. Areas of Learning and Vocational Spheres of Activity are both grouping principles. On the other hand these two approaches are different: While Areas of Learning are legal requirements for vocational schools, Vocational Spheres of Activity focus the real work; while Areas of Learning are a result of a negotiation process, Vocational Spheres of Activity are empirically grounded in the skilled work; while Areas of Learning are defined in more general terms, Vocational Spheres of Activity are concrete and specifying work objects, tools, regulations, phases, the work process and work steps. A task for teachers is therefore to combine the legal requirements for schools, as defined in the Areas of Learning, with the concrete demands of the work life, as defined in the Vocational Spheres of Activity. 


\section{Tab. 6: Excerpt from a vocational sphere of activity: Specifications and Trends}

\begin{tabular}{|c|c|c|}
\hline \multicolumn{2}{|c|}{ Specifications } & \multirow[b]{2}{*}{$\begin{array}{l}\text { Trends } \\
\text { Building automation and } \\
\text { energy management (KNX } \\
\text { Standard, home server, } \\
\text { smart metering), video and } \\
\text { voice technology (voice } \\
\text { over ip, wireless LAN), } \\
\text { alarm systems (e.g. smoke) }\end{array}$} \\
\hline $\begin{array}{l}\text { Work } \\
\text { objects }\end{array}$ & $\begin{array}{l}\text { Meter cabinet, small distribution board, junction } \\
\text { box, switch box, lights, switches, sockets, fuses, } \\
\text { circuit breaker, residual current circuit breaker (FI), } \\
\text { cabling, cables, conduit }\end{array}$ & \\
\hline Tools etc. & $\begin{array}{l}\text { Tools: stripping knife, wire stripper, crimping } \\
\text { pliers, screwdriver, wire cutter, hammer, chisel } \\
\text { Machineries: drill, core drill bits, channel cutter, } \\
\text { Duspol voltage tester, multimeter, testing device } \\
\text { (VDE) } \\
\text { Documents: circuit plans, installation plan, } \\
\text { measurement form, distribution plan, time sheet, } \\
\text { delivery note, catalogue (light switches), price list } \\
\text { Software: Powerbird (calculation, project } \\
\text { management, administration, material lists), Dialux } \\
\text { (Lightning planning) }\end{array}$ & $\begin{array}{l}\text { Cloud computing and } \\
\text { software as a service (SaaS) }\end{array}$ \\
\hline $\begin{array}{l}\text { Laws, } \\
\text { Norms, } \\
\text { Standards } \\
\text { and } \\
\text { regulations }\end{array}$ & $\begin{array}{l}\text { Laws: Civil Code } \$ 437 \text { (rights of the costumer), } \S \\
\text { 631-651 (private contracts), .. } \\
\text { Norms, Standards: German Industrie Norm DIN } \\
\text { VDE 0298-4 (use of cables and insulating cabling), } \\
\ldots \\
\text { Regulations: Trade Association Regulations BGV } \\
\text { A } 3 \text { (Electrical systems and operating equipment), } \\
\ldots\end{array}$ & $\begin{array}{l}\text { New laws for energy } \\
\text { management }\end{array}$ \\
\hline
\end{tabular}

The next step comprises developing a vocational learning situation for the classroom. Work process oriented projects are planned for this that are implemented in four work stages: order/problem clarification, planning, execution, and completion. These four stages are framed by the "start" stage at the beginning and the "evaluation" stage at the end. The four work stages ensure that the essential action steps and design aspects of a working process are taken into account. The two additional stages, start and evaluation, confirm the learning potentials and systematisation and assurance of the knowledge gained through experience (Gessler and Uhlig-Schoenian 2013).

\section{$5 \quad$ Grounded Work-Based Learning}

The start stage pursues the intention to establish a consensual basic understanding of the underlying order or the underlying problem and then to put the task in the overall context of education. Teachers, with the involvement of the learners, thus consider what the task is about, what is intended with the task, and what can be linked in terms of knowledge and skills as well as experience. In terms of the underlying work order, the work process-related project refers to producing a (partial) product or providing a service or to overcoming a professional problem. To do this, the students carry out the required activity steps in the different work stages. The students of course must first develop the skills to successfully meet the requirements of the individual work stages. The targeted encouragement of professional competence, social skills, and personal skills thus occurs linked to the 
action steps to be run through and embedded in directly processing the task. The final evaluation stage serves first to abstract, systemise, and critically reflect on what was experienced with a specific learning and work process, and second to individually assess which skills were developed in the process. Work and projectbased courses and learning thus consists of six stages: (1) start, (2) order/problem clarification, (3) planning, (4) implementation, (5) completion, (6) evaluation.

The development of such a project is ideally carried out in eight stages.

\section{Analysis of reference: Curriculum and Vocational Spheres of Activity}

The core questions are: Which key goals are formulated in the curriculum? Which vocational and cross-vocational thematic areas do the curriculum focus on? What relationship can be seen between the curriculum and the vocational sphere of activity?

\section{Analysis of the requirements and general conditions}

First, it is necessary to perform a conditions analysis (e.g. Peterßen 2000) in order to be clear about the essential points of the starting position. A conditions analysis refers to two main areas: In the personnel requirements, it is necessary to address the size and composition of the group and of students as well as the relevant skills and experience for the planned task that the students have already acquired. Second, checking the personnel requirements relate to the question of how teachers should be involved in the task. For the organisational and institutional framework, it needs to clarify what time frame and what equipment at which point are available for the grounded work-based learning projects.

\section{Specifying a vocational sphere of activity for class}

Core questions are: Which vocational work processes or rather vocational work phases should the learning situation's focal areas fall on? Which working tools and methods and which elements of the vocational competence to act are important to the learning situation within the area of learning? Which task is exemplary and relevant for the underlying vocational sphere of activity? Is the task suitable to the developmental level of the learner in terms of complexity, requirements and scope? Does the task allow for various solution possibilities? Can the task be carried out at school? What is the wording of the task for the students? In concrete terms, what are the focal areas for competence-building within the learning situations? What is the key content to be processed within the task set? Which competences are needed to tackle the task and what competences do the students already possess? Can the gap be closed through self-organised learning or do supplementary subject-oriented educational units need to be planned in? When are these subject-oriented educational units to be implemented in concrete terms?

\section{Description of a scenario}

In scenario (1), it should be noted what product is to be produced or what service is to be provided for the grounded work-based learning projects. To illustrate the integration of the task, students must also present (2) who the contracting authority is, (3) what are the expectations for the work results, and (4) what must be taken into account from the resulting conditions of the learning and working environment. 
5 Establishing the steps to be undertaken, goals, and content

This sub step is the most important for developing a grounded work-based learning project. Establishing the steps to be undertaken, goals, and content of the task are intertwined and mutually influence each other. All decisions are (1) to be made with a perspective of the scenario, (2) must be made on the basis of curricular requirements, and must (3) consider the findings of the conditions analysis. The reference for a grounded work-based learning project is a real work process that is initiated by a work order. In this setting, it is first necessary to define the steps that must be undertaken for each work stage that the students have to complete in the course of performing this task. At the same time it should be considered which professional, social, and personal skills the students need for this to encourage them accordingly - as goals of the work-based learning project. The third question must answer what content the students are confronted with when performing the task and how the proposed goals are to be achieved. Decisions regarding content in general are to be made with respect to the necessary professional, scientific, or mathematical principles of the work items used (products, equipment, systems, devices, machinery, components, assemblies, subsystems) and resources (tools, materials, PC/software, documentation) as well as the laws, regulations, and standards.

\section{Determining the subtasks}

In order to determine the individual subtasks or issues that the students are to carry out, the steps, goals and content must be merged with matching "bundles". They must therefore consider what goals with what content in what steps must be performed for the subtask. In principle, two types of subtasks can be distinguished. Process-oriented formulated tasks are based on the work process flow and relate directly to one or more steps. Content is directly linked to the steps and is thus an integral component. In contrast, there is specific content in the focus of themeoriented formulated subtasks. The reference to the work process and steps to be undertaken is made only after elaboration of the theme and then flows into the rest of the grounded work-based learning project. In developing the subtasks, methodological considerations are also employed, i.e. they must reflect on what training or teaching methods the subtask should be appropriately implemented (Howe and Knutzen 2012b). Second, they must specify what materials are needed for medial treatment and support for the subtask.

\section{Draft of a schedule and work plan}

In the last substep, the individual subtasks are merged, taking into account the conditions analysis for a provisional schedule and work plan. This plan represents an overall view of the grounded work-based learning project, which refers to the interaction of the individual subtasks to the final overall results of the task and the integrated resources (colleagues, rooms/facilities, hours, etc.).

\section{Final reflection}

Experience shows that all planning elements do not immediately merge into a coherent, non-contradictory overall concept so there are modifications to the previously adopted plans: The development of a grounded work-based learning project is not stringently consistent, but an iterative process that is always characterised by corrections and adjustments in terms of feedback loops. 
The core questions are: What competences will the students develop within this learning situation with separate evaluations of professional, social and personal competences? How can the intended knowledge be linked and structured into a systematic relationship? How can the knowledge gained be transferred to other situations and what modifications would be required in this case?

\section{Conclusion and future prospects}

Grounded Work-based Learning Projects describes a didactic approach which represents vocational work process oriented learning in problematic situations in an operational reality. The term grounded work-based learning projects indicates that learning and work are linked and systematically related to each other. The overarching goal of the integrated delivery of theoretical knowledge and practical skills by means of learning and work assignments is the development of comprehensive professional expertise. Moreover, the learners should recognise during their workbased teaching and learning that technology is purpose-oriented and can be shaped, and that working processes can be organised in very different ways. In this context, our approach has the following characteristics:

- Grounded work-based learning projects do not only support the acquisition of specialist occupational content and skills, it also gives targeted support to the development of personal and social competence.

- Grounded work-based learning projects give the students some leeway with regard to actions and decision. The apprentices leave behind their accustomed role from their school days which tends to be that of a passive consumer and they go on to learn mainly independently, organising themselves and taking responsibility for themselves.

- In grounded work-based learning projects, the relationship to a concrete vocational work process is established. This facilitates a better transfer of the learning to comparable assignments, cases and problems.

- The interest of the apprentices in the subject matter is stimulated where a concrete occupational assignment is linked to the grounded work-based teaching and learning. The apprentices experience the feeling of doing something worthwhile.

The evaluation of grounded work-based learning projects is hands-on vocational training research. Research results and advice from different pilot projects can be summarised with the conclusion that the grounded work-based approach has proven successful. In the studies a new quality of education is emphasised that is appropriate to current professional challenges. At the end of their training, young people proved to have grown confident with the acquired skills for everyday work and future challenges. In turn, human resource managers emphasised that the apprentices integrated into the company largely without problems. In addition to the grounded work-based didactic concept, educators and teachers rated the high level of motivation and commitment of apprentices and students as especially crucial for this type of education structure (Arends et al. 1998; Bunzel et al. 1998; Höpfner 1998; Jenewein 1999; Malek and Pahl 1998; Wilke-Schnaufer et al. 1998). Despite these generally positive findings, the implementation of action and workprocess oriented concepts in vocational education and training is still in process. The studies conducted on this show that a teacher-centered approach is often used (Pätzold et al. 2003; Seifried 2009). Innovation efforts in the class and training 
structure are still restricted by traditional regulations that barely connect the school and company part of vocational training content (Reetz 2000), although the situation has improved: in particular, the areas of learning concept for the structure of school curricula (KMK 2011) support allocation that is oriented towards professional actions and tasks. The introduction of the areas of learning in this context mean an appreciation of grounded work-based learning, because this concept demand a didactic implementation of the curriculum in the form of workprocess oriented teaching and learning.

The educational-political change of control of educational systems in Germany from an input to an output orientation (Klieme et al. 2003) or from a mediation perspective to an application and utilisation perspective (Sloane and Dilger 2005) on the other hand meant that the problem of skill measuring has largely supplanted the didactic problem of skill development. Since measurement is confounded with tests and tests act as structure-building in classes and training, it is tempting in practice to have a training-to-the-test attitude. Much progress has been achieved in recent years in the area of psychometric skill measurement (e.g. ZBW 2015). What is important now, however, is that considerations of skillpromoting design of learning processes in vocational training research become more important again. The few studies and conceptual contributions in recent years (e.g. Bauer and Koring 2008; Howe 2008; Schröder 2009; Koring et al. 2009; Howe and Knutzen 2012a; Lehberger 2013) show that research findings may support vocational education and training practice. In this regard, there is reason for hope in the "Riga Conclusions" of the European Ministries of Education of 22 June 2015 for the orientation of vocational education and training in Europe. As "medium-term deliverables" for 2015 to 2020, promoting work-based learning is the first suggestion - based on a "learning outcome approach" (European Commission 2015, p. 4). Design-based and outcome-oriented research as complementary partners may give new impetus to the spread and development of grounded work-based learning and teaching. Just, also the outcome-oriented research should be grounded in the reality of work. 


\section{References}

Adolph, G. (1996). Handlungsorientierter Technikunterricht. In A. Lipsmeier, \& F. Rauner (Eds.), Beiträge zur Fachdidaktik Elektrotechnik (pp. 180-195). Stuttgart: Holland + Josenhans.

Arbeitskreis Deutscher Qualifikationsrahmen (2011). Deutscher Qualifikationsrahmen für lebenslanges Lernen. URL: http://www.dqr.de/content/2453.php. Accessed 27 August 2015.

Arends, E., Ehrlich, K., Meyer, R., \& Uhlig-Schoenian, J. (1998). Modellversuch KONSIL: Kontinuierliche Selbstorganisation im Lernortverbund Berufsschule-Betrieb des neuen Berufs Prozessleitelektroniker/-in. In H. Holz, F. Rauner, \& G. Walden (Eds.), Ansätze und Beispiele der Lernortkooperation (pp. 135-149). Bielefeld: Bertelsmann.

Bundesagentur für Arbeit (2010). Klassifikation der Berufe 2010: Systematischer und alphabetischer Teil mit Erläuterungen. Volume 1. Nuremberg: Bundesagentur für Arbeit.

Bundesagentur für Arbeit (2015). Klassifikation der Berufe 2010: Alphabetisches Verzeichnis der Berufsbenennungen. Update: 30 March 2015. Nuremberg: Bundesagentur für Arbeit.

Bauer, W., \& Koring, C. (2008). Arbeitsorientierte Weiterbildung für an- und ungelernte Beschäftigte. Ein Beispiel aus der Metall- und Elektroindustrie. BWP Berufsbildung in Wissenschaft und Praxis, 2, 21-25.

Bundesinstitut für Berufsbildung (2006). Ausbildungsordnungen und wie sie entstehen. Bonn: BIBB.

Bundesinstitut für Berufsbildung (2015). Datenreport zum Berufsbildungsbericht. Informationen und Analysen zur Entwicklung der beruflichen Bildung. Bonn: BIBB.

Burchert, J., Hoeve, A., \& Kämärainen, P. (2014). Interactive Research in Vocational Education and Training (VET): Lessons from Durch and German cases. International Journal for Research in Vocational Education and Training, 1(2), 143-160.

BMBF Bundesminister für Bildung und Forschung (1997). Ausbilden im Verbund: Tips und Anregungen für kleine und mittlere Betriebe mit zahlreichen Praxisbeispielen. Bielefeld: Bertelsmann.

Boekaerts, M. (1999). Self-regulated learning: where we are today. International Journal of Educational Research, 31(6), 445-457.

Bunzel, W., Schäfer, H., \& Bretheuer, K.-O. (1998). Modellversuch Arbeitsorientierte Berufsbildung (ARBI). In H. Holz, F. Rauner, \& G. Walden (Eds.), Ansätze und Beispiele der Lernortkooperation (pp. 271-292). Bielefeld: Bertelsmann.

Cognition and Technology Group at Vanderbilt (1990). Anchored instruction and its relationship to situated cognition. Educational Researcher, 19(3), 2-10.

Collins, A., Brown, J.S., \& Newman, S.E. (1989). Cognitive apprenticeship: Teaching the crafts of reading, writing and mathematics. In L.B. Resnick (Ed.), Knowing, learning and instruction (pp. 453-494). Hillsdale: Lawrence Erlbaum Associates.

Dehnbostel, P. (2002). Dezentrales Lernen als vernetztes und reflexives Lernen im Prozess der Arbeit. In M. Fischer, \& F. Rauner (Eds.), Lernfeld: Arbeitsprozess (pp. 341-354). Baden-Baden: Nomos.

Dehnbostel, P. (2007). Lernen im Prozess der Arbeit. Münster: Waxmann. 
Dehnbostel, P., Holz, H., \& Novak, H. (1992). Lernen für die Zukunft durch verstärktes Lernen am Arbeitsplatz: Dezentrale Aus- und Weiterbildungskonzepte in der Praxis. Berlin: BIBB.

Deutscher Bildungsrat (1972). Empfehlungen der Bildungskommission: Strukturplan für das Bildungswesen. 4th edition. Stuttgart: Klett.

European Commission (2015). Riga Conclusions 2015 on a New Set of MediumTerm Deliverables in the Field of VET for the Period 2015-2020, as a Result of the Review of Short-Term Deliverables defined in the 2010 Bruges Communiqué. Brussels: European Commission.

Faulstich, P., Gnahs, D., Seidel, S., \& Bayer, M. (2002). Praxishandbuch selbstbestimmten Lernens: Konzepte, Perspektiven und Instrumente für die berufliche Aus- und Weiterbildung. Weinheim: Juventa.

Frieling, E. (1995). Lernen und Arbeiten. In R. Arnold, A. Lipsmeier (Eds.), Handbuch der Berufsbildung (pp. 261-270). Opladen: Leske + Budrich.

Gerds, P. (2001). Der Lernfeldansatz: Ein Weg aus der Krise der Berufsschule? In P. Gerds, \& A. Zöller (Eds.), Der Lernfeldansatz der Kultusministerkonferenz (pp. 20-51.). Bielefeld: Bertelsmann.

Gerstenmaier, J., \& Mandl, H. (1995). Wissenserwerb unter konstruktivistischer Perspektive. Zeitschrift für Pädagogik, 41(6), 867-888.

Gessler, M. (2009). Situational Learning and Cognitive Apprenticeship. In R. MacLean, \& D. Wilson (Eds.), International Handbook of Education for the Changing World of Work. Bridging Academic and Vocational Learning (pp. 1611-1625). Berlin: Springer.

Gessler, M. (2010). Das Kompetenzmodell. In R. Bröckermann, \& M. MüllerVorbrüggen (Eds.), Handbuch Personalentwicklung: die Praxis der Personalbildung, Personalförderung und Arbeitsstrukturierung (pp. 43-62). 3rd edition. Stuttgart: Schäffer-Poeschel.

Gessler, M. (2010). Selbstorganisiertes Lernen und lernende Organisation. In R. Bröckermann, \& M. Müller-Vorbrüggen (Eds.), Handbuch Personalentwicklung: die Praxis der Personalbildung, Personalförderung und Arbeitsstrukturierung (pp. 263-282). 3rd edition. Stuttgart: Schäffer-Poeschel.

Gessler, M., \& Uhlig-Schoenian, J. (2013). Projektmanagement macht Schule: Ein handlungsorientierter Leitfaden für den Unterricht in der Sekundarstufe II. 5th edition. Nuremberg: GPM.

Gessler, M., \& Howe, F. (2013). The German dual vocational training system: The origin of the current architecture. Bulletin of Institute of Technology and Vocational Education (Nagoya University, Japan), 10, 17-28.

Gessler, M. (2016). Areas of Learning: The shift towards work and competence orientation within the School-based Vocational Education in the German Dual Apprenticeship System. In M. Mulder, \& J. Winterton (Eds.), CompetenceBased Vocational and Professional Education: Bridging the World of Work and Education (pages not jet available). Cham: Springer International Publishing.

Greeno, J.G., Smith, D.R., \& Moore, J.L. (1993). Transfer of situated learning. In D.K. Dettermann, \& R.J. Sternberg (Eds.), Transfer on trial: Intelligence, cognition, and instruction (pp. 99-167). Norwood: Ablex Publishing.

Greinert, W.-D., \& Wolf, S. (2013). Die Berufsschule: Radikale Neuorientierung oder Abstieg zur Restschule? 2nd edition. Berlin: TU Berlin University Press.

Holz, H., Koch, J., Schemme, D., \& Witzgall, E. (Eds.). (1998). Lern- und Arbeitsaufgabenkonzepte in Theorie und Praxis. Bielefeld: Bertelsmann. 
Höpfner, H.-D. (1998). Das Konzept der Lern- und Arbeitsaufgaben als Grundlage einer lernortintegrierenden Ausbildungsgestaltung in einem doppelt qualifizierenden Bildungsgang. In K. Jenewein (Ed.), Theorie und Praxis der Lernortkooperation in der gewerblich-technischen Berufsausbildung (pp. 103-123). Neusäß: Kieser.

Howe, F. (2008). Software- und internetgestützte Lern- und Arbeitsaufgaben in der überbetrieblichen Ausbildung. In F. Howe, J. Jarosch, \& G. Zinke (Eds.), Ausbildungskonzepte und Neue Medien in der überbetrieblichen Ausbildung (pp. 47-73). Bielefeld: Bertelsmann.

Howe, F., \& Knutzen, S. (2011a). Analysieren und Beschreiben von Arbeitsprozessen. Volume 2. Constance: Christiani.

Howe, F., \& Knutzen, S. (2011b). Beschreiben von Beruflichen Handlungsfeldern. Volume 3. Constance: Christiani.

Howe, F., \& Knutzen, S. (2012a). Entwickeln von Lern- und Arbeitsaufgaben. Volume 4. Constance: Christiani.

Howe, F., \& Knutzen, S. (2012b). Verwenden von Ausbildungs- und Unterrichtsmethoden. Volume 5. Constance: Christiani.

Howe, F., \& Knutzen, S. (2014). Beschreiben von Berufen: Berufsspezifische Anpassungen der Kompetenzwerkst@tt durch Experten-Workshops. Volume 10. Constance: Christiani.

Hüster, W., \& Gravert, H. (2001). Intentionen der KMK bei der Einführung von Lernfeldern. In P. Gerds (Ed.), Der Lernfeldansatz: ein Weg aus der Krise der Berufsschule? (pp. 83-97.). Bielefeld: Bertelsmann.

Jenewein, K. (Ed.). (1999). Lernen und Arbeiten in der dualen Berufsausbildung. Bremen: Donat.

Johnson, D. W., \& Johnson, R.T. (2003). Student motivation and co-operative groups: social interdependence theory. In R.M. Gillies, \& A.F. Ashman (Eds.), Co-operative learning: The social and intellectual outcomes of learning in groups (pp. 136-176). New York: RoutledgeFalmer.

Kerschensteiner, G. (1901). Staatsbürgerliche Erziehung der deutschen Jugend. Gekrönte Preisschrift. Erfurt: Carl Villaret.

Kerschensteiner, G. (1922). Begriff der Arbeitsschule. 5th edition (1st edition 1911). Leibzig: Teubner.

Klieme, E., Avenarius, H., Blum, W., Döbrich, P., Gruber, H., Prenzel, M., Reiss, K., Riquarts, K., Rost, J., Tenorth, H.-E., \& Vollmer, H. (2003). Zur Entwicklung nationaler Bildungsstandards: Eine Expertise. Berlin: BMBF.

KMK (1991). Rahmenvereinbarung über die Berufsschule. Bonn: Sekretariat der Ständigen Konferenz der Kultusministerien der Länder in der Bundesrepublik Deutschland.

KMK (1996/1999). Handreichungen für die Erarbeitung von Rahmenlehrplänen der Kultusministerkonferenz (KMK) für den berufsbezogenen Unterricht in der Berufsschule und ihre Abstimmung mit Ausbildungsordnungen des Bundes für anerkannte Ausbildungsberufe. Bonn: Sekretariat der Ständigen Konferenz der Kultusministerien der Länder in der Bundesrepublik Deutschland.

KMK (2011). Handreichungen für die Erarbeitung von Rahmenlehrplänen der Kultusministerkonferenz (KMK) für den berufsbezogenen Unterricht in der Berufsschule und ihre Abstimmung mit Ausbildungsordnungen des Bundes für anerkannte Ausbildungsberufe. Bonn: Sekretariat der Ständigen Konferenz der Kultusministerien der Länder in der Bundesrepublik Deutschland. 
Knöll, B., Gschwendtner, T., Nickolaus, R., \& Ziegler, B. (2007). Motivation in der elektrotechnischen Grundbildung. Zeitschrift für Berufs- und Wirtschaftspädagogik, 103(3), 397-415.

Knowles, M. (1975). Self-Directed Learning. Chicago: Follet.

Knutzen, S., Howe, F., \& Hägele, T (2010). Arbeitsprozessorientierung in der Beruflichen Bildung: Analyse und Beschreibung von Arbeitsprozessen mit Hilfe der Arbeitsprozessmatrix. In M. Becker, M. Fischer, \& G. Spöttl (Eds.), Von der Arbeitsanalyse zur Diagnose beruflicher Kompetenzen (pp. 90-110). Frankfurt: Peter Lang.

Koring, C., Stroot, I., \& Röben, P. (2009). Abschlussbericht: Projekt Weiterbildung im Prozess der Arbeit für an- und ungelernte Beschäftigte in der Metallindustrie in Baden-Württemberg. Bremen: Institute Technology and Education.

Laur-Ernst, U., Albert, K., \& Gutschmidt, F. (1996). Komplexe Aufgaben gemeinsam lösen: Projektarbeiten zur Elektronik. 6 Volumes. Berlin: Beuth.

Lave, J., \& Wenger, E. (1991). Situated learning: Legitimate peripheral participation. Cambridge, UK: Cambridge University Press.

Lehberger, J. (2013). Arbeitsprozesswissen - didaktisches Zentrum für Bildung und Qualifizierung. Berlin: Lit.

Lipsmeier, A. (1996). Lernen und Arbeiten. In B. Bonz (Ed.), Didaktik der Berufsbildung (pp. 205-219). Stuttgart: Holland + Josenhans.

Lipsmeier, A. (1998). Berufsbildung. In C. Führ, \& C.-L. Furck (Eds.), Handbuch der deutschen Bildungsgeschichte: 1945 bis zur Gegenwart (pp. 447-489). München: Beck.

Locke, A.E., \& Latham, G.P. (2002). Building a Practically Useful Theory of Goal Setting and Task Motivation: A 35-Year Odyssey. American psychologist, 57(9), 705-717.

Malek, R., \& Pahl, J.-P. (1998). Kooperationsfördernde Lern- und Arbeitsaufgaben - ein Beitrag zur handlungsorientierten Instandhaltungsausbildung. In H. Holz, F. Rauner, \& G. Walden (Eds.), Ansätze und Beispiele der Lernortkooperation (pp. 237-256). Bielefeld: Bertelsmann.

Mandl, H., Gruber, H., \& Renkl, A. (2002). Situiertes Lernen in multimedialen Lernumgebungen. In L.J. Issing, \& P. Klimsa (Eds.), Information und Lernen mit Multimedia und Internet (pp. 139-148). Weinheim: Beltz PVU.

Mertens, D. (1974). Schlüsselqualifikationen: Thesen zur Schulung für eine moderne Gesellschaft. Mitteilungen, Arbeitsmarkt und Berufsforschung, 7, $36-43$.

Palla, R. (2014). Verschwundene Arbeit. Das Buch der untergegangenen Berufe. Vienna: Brandstätter.

Pätzold, G. (Ed.). (1992). Handlungsorientierung in der beruflichen Bildung. Frankfurt a.M.: Verlag der Gesellschaft zur Förderung arbeitsorientierter Forschung und Bildung.

Pätzold, G., Klusmeyer, J., Wingels, J., \& Lang, M. (2003). Lehr-Lern-Methoden in der beruflichen Bildung. Eine empirische Untersuchung in ausgewählten Berufsfeldern. Oldenburg: University Oldenburg.

Pätzold, G., \& Walden, G. (1999). Lernortkooperation - Stand und Perspektiven. Bielefeld: Bertelsmann.

Peterßen, W.H. (2000). Handbuch Unterrichtsplanung. München: Oldenbourg.

Pólya, G. (1964). Die Heuristik. Versuch einer vernünftigen Zielstellung. Der Mathematikunterricht, 1, 5-15. 
QUEM Arbeitsgemeinschaft Qualifikations-Entwicklungs-Management (Eds.). (2000). Kompetenzentwicklung 2000. Münster: Waxmann.

Rauner, F. (1988). Die Befähigung zur (Mit-)Gestaltung von Arbeit und Technik als Leitidee beruflicher Bildung. In G. Heidegger, P. Gerds, \& K. Weisenbach (Eds.), Gestaltung von Arbeit und Technik - ein Ziel beruflicher Bildung (pp. 32-50). Frankfurt: Campus.

Rauner, F. (1995). Gestaltungsorientierte Berufsbildung. berufsbildung, 35, 3-8.

Rauner, F. (2003). Ausbildungspartnerschaften als Regelmodell für die Organisation der dualen Berufsausbildung. In J.-P. Pahl, F. Schütte, \& B. Vermehr (Eds.), Verbundausbildung (pp. 151-174). Bielefeld: Bertelsmann.

Reetz, L. (1984). Wirtschaftsdidaktik. Bad Heilbrunn: Klinkhardt.

Reetz, L. (1990). Zur Bedeutung der Schlüsselqualifikation in der Berufsbildung. In L. Reetz, \& T. Reitmann (Eds.), Schlüsselqualifikation. Dokumentation eines Symposiums in Hamburg (pp. 16-35). Hamburg: Berufsförderungswerk Hamburg.

Reetz, L. (2000). Handlung, Wissen und Kompetenz als strukturbildende Merkmale von Lernfeldern. In R. Bader, \& P.F.E. Sloane (Eds.), Lernen in Lernfeldern: Theoretische Analysen und Gestaltungsansätze zum Lernfeldkonzept. Markt Schwaben: Eusl.

Robinsohn, S.B. (1967). Bildungsreform als Revision des Curriculum. Neuwied: Luchterhand.

Rogoff, B. (1990). Apprenticeship in thinking. Cognitive development in social context. New York: Oxford University Press.

Roth, H. (1971). Pädagogische Anthropologie. Entwicklung und Erziehung. Grundlagen einer Entwicklungspädagogik. Volume 2. Hannover: Schroedel.

Schröder, T. (2009). Arbeits- und Lernaufgaben für die Weiterbildung: Eine Lernform für das Lernen im Prozess der Arbeit. Bielefeld: Bertelsmann.

Schulz-Hardt, S., Hertel, G., \& Brodbeck, C.F. (2007). Gruppenleistung und Leistungsförderung. In H. Schuler, \& K. Sonntag (Eds.), Handbuch der Arbeits- und Organisationspsychologie (pp. 698-706). Göttingen: Hogrefe.

Seifried, J. (2009). Unterricht aus Sicht von Handlungslehrern. Frankfurt: Peter Lang.

Sloane, P.F.E., \& Dilger, B. (2005). The competence clash: Dilemmata bei der Übertragung des 'Konzepts der nationalen Bildungsstandards' auf die berufliche Bildung.bwp@Berufs- und Wirtschaftspädagogik online, 8, 1-32.

Weinert, F.E. (1994). Lernen lernen und das eigene Lernen verstehen. In K. Reusser, \& M. Reusser-Weyeneth (Eds.), Verstehen: Psychologischer Prozess und didaktische Aufgabe (pp. 183-205). Bern: Hans Huber.

Wilke-Schnaufer, J., Schonhardt, M., Frommert, H., \& Weidhaas, H. (1998). Lernund Arbeitsaufgaben für die Berufsbildung. Bielefeld: Bertelsmann.

Wittwer, W. (2000). Methoden der Ausbildung: Didaktische Werkzeuge für Ausbilder. Köln: Deutscher Wirtschaftsdienst.

ZBW (2015). Zeitschrift für Berufs- und Wirtschaftspädagogik, 111(2), 161-294 (with contributions from R. Nickolaus, A. Balkenhol, R. Bernhardt, A. Frey, C. Spoden, B. Ziegler, S. Brandt, T. Martens, A. Rausch, J. Seifried, D. Sembill, K. Wolf, E. Wuttke, B. Geißel, N. Link, N. Link, R. Nickolaus, F. Walker, M. Liedtke, S. Seeber, S. Bley, S. Weber, M. Wiethe-Körprich). 